\title{
Arthropod Surveys on Palmyra Atoll, Line Islands, and Insights into the Decline of the Native Tree Pisonia grandis (Nyctaginaceae) ${ }^{1}$
}

\author{
Alex T. Handler, ${ }^{2,3,7}$ Daniel S. Gruner $, 3,4$ William P. Haines, ${ }^{5}$ Matthew W. Lange, ${ }^{6}$ \\ and Kenneth Y. Kaneshiro ${ }^{3}$
}

\begin{abstract}
Palmyra Atoll, in the Line Islands of the equatorial Pacific, supports one of the largest remaining native stands of Pisonia grandis forest in the tropical Pacific Ocean. In 2003, we surveyed terrestrial arthropods to document extant native and introduced species richness, compare these lists with historical records, and assess potential threats to native species and ecosystem integrity. In total, 115 arthropod taxa were collected, bringing the total number of taxa recorded since 1913 to 162 . Few native species were collected; most taxa were accidental introductions also recorded from the Hawaiian Islands, the presumed main source of introductions to Palmyra. The overlap with previous historical surveys in 1913 and 1948 was low $(<40 \%)$, and new species continue to establish, with one species of whitefly reaching pest status between 2003 and 2005. We observed numerous dead or dying large Pisonia grandis, and the green scale Pulvinaria urbicola (Coccidae) was particularly abundant on trees of poor health. Abundant introduced ants, particularly Pheidole megacephala, tended this and other hemipterans feeding on both native and introduced plants. We hypothesize that the Pheidole-Pulvinaria facultative mutualism is causing the decline of Pisonia grandis. Because of the unique properties of Pisonia grandis forest on oceanic atolls, its importance for nesting seabirds, and its alarming global decline, immediate conservation efforts should be directed at controlling introduced Hemiptera and disrupting their mutualisms with nonnative ants on Palmyra Atoll.
\end{abstract}

As BIOGEOGRAPHIC BARRIERs break down in the face of increasing global commerce and

\footnotetext{
${ }^{1}$ Funding for this work was provided by NSF GK-12 Grant no. DGE02-32016 and the U.S. Fish and Wildlife Service. This is contribution no. 2368, Bodega Marine Laboratory, University of California at Davis, Davis, California. Manuscript accepted 7 January 2007.

${ }^{2}$ Corresponding author: alex@joulejunction.com.

${ }^{3}$ Center for Conservation Research and Training, University of Hawai'i at Mānoa, Honolulu, Hawai'i 96822.

${ }^{4}$ Bodega Marine Laboratory, University of California at Davis, Bodega Bay, California 94923.

${ }^{5}$ Department of Plant and Environmental Protection Sciences, University of Hawai'i at Mānoa, Honolulu, Hawaici 96822 .

${ }^{6}$ The Nature Conservancy, Palmyra Atoll National Wildlife Refuge.

${ }^{7}$ PowerPlants Hawaii LLC, Honolulu, Hawai' $i$ 96816.
}

Pacific Science (2007), vol. 61, no. 4:485-502

(C) 2007 by University of Hawai'i Press

All rights reserved travel, introduced species have become a dominant component of global environmental change (Vitousek et al. 1999, Mack et al. 2000). Oceanic islands are among the systems most vulnerable to biological invasion and homogenization (D'Antonio and Dudley 1995, Cowie 2001). Their small size allows coexistence of fewer total species in small populations relative to continents, and their native biota evolved in geographic isolation from many functional forms of predation and competition (Carlquist 1974, Wilson 1996, Whittaker 1998). Although the replacement of endemic species by introduced species may actually increase local species and functional diversity on islands (Sax and Gaines 2003), regional homogenization of biotic communities causes decline in total global diversity (Samways 1999, Olden et al. 2004).

Palmyra is a remote atoll in the northern Line Islands (Figure 1), approximately 2,000 $\mathrm{km}$ south-southwest of the Hawaiian Ar- 


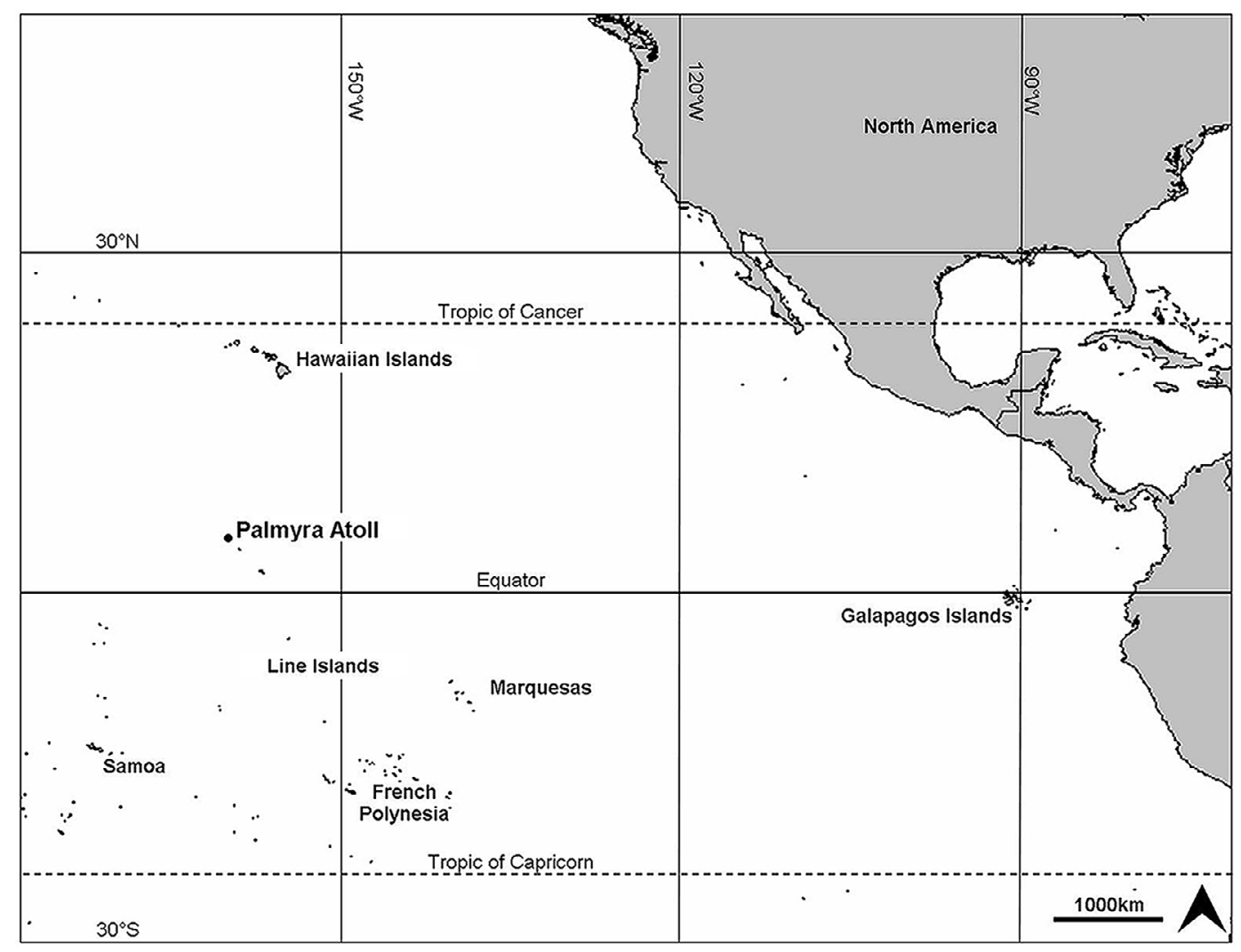

Figure 1. Palmyra Atoll, northern Line Islands, equatorial Pacific Ocean.

chipelago (5 $\left.53^{\prime} 6^{\prime \prime} \mathrm{N}, 162^{\circ} 6^{\prime} 11^{\prime \prime} \mathrm{W}\right)$. The atoll consists of roughly 50 small, low islets, with a total land area of less than $5 \mathrm{~km}^{2}$ and a maximum elevation of $2 \mathrm{~m}$, all surrounded by a barrier reef. With an average annual rainfall of more than $4 \mathrm{~m}$, Palmyra is a wet atoll within the Inter-tropical Convergence Zone (Mueller-Dombois and Fosberg 1998). This high rainfall, coupled with huge nutrient influx in the form of guano from thousands of resident seabirds and migratory shorebirds, supports thickly vegetated rain forest that is unique even in comparison with nearby, more arid islands such as Kiritimati (Wester 1985). The atoll is home to a relatively intact and diverse marine ecosystem; 29 species of birds; the coconut crab (Birgus latro L.), the world's largest terrestrial arthropod (Reyne 1939, Chauvet and Kadiri-Jan 1999); and rare stands of Pisonia grandis R. Br. (Nyctaginaceae). Many of these native species are listed as threatened or endangered because of historical human exploitation and habitat disturbance throughout their ranges and continued impacts of introduced species (IUCN 2004).

Palmyra probably did not support persistent populations of indigenous peoples, although there is evidence of sporadic Polynesian occupation (Dawson 1959, Wester 1985). However, in the brief 200-yr history since European seafarers stumbled upon it, intense human disturbance has severely impacted the atoll (Dawson 1959). Fanning first sighted the atoll in 1798, but it was named when an American ship, The Palmyra, drifted onto its shores after a storm on 7 November 1802. In 1862, Kamehameha IV claimed Pal- 
myra as part of the Hawaiian Kingdom. Palmyra Atoll was recognized in turn as a U.S. territory with the annexation of Hawaic $i$ in 1898. The atoll passed variously through public and private ownership until 2001, including a period of intense military occupation from 1938 to 1961. During that period, the U.S. Navy dredged lagoons and built bunkers, recreation centers, an airstrip, a hospital, and causeways connecting islets. During peak occupancy, the 182 ha of land area supported over 6,000 naval personnel and substantial infrastructure (Dawson 1959, Anon. 1998). In 2001, Palmyra Atoll was designated a National Wildlife Refuge of the U.S. Fish and Wildlife Service. Currently, Palmyra Atoll is jointly owned and managed by The Nature Conservancy and the U.S. Fish and Wildlife Service (Anon. 1998) and is uninhabited except for a small cadre of scientists, resource managers, and transient crew.

The hallmark indigenous plant species of the atoll is Pisonia grandis, which grows to heights often exceeding $30 \mathrm{~m}$ in dense monodominant stands in some of the largest tracts remaining on tropical Pacific islands (Walker 1991a, Mueller-Dombois and Fosberg 1998). With sticky fruits dispersed by seabirds (Airy Shaw 1952, Burger 2005), P. grandis forests are widespread throughout the Indo-Pacific region but are often locally rare and declining within their native range (Walker 1991a, Mueller-Dombois and Fosberg 1998, Kay et al. 2003). On Palmyra Atoll, $P$. grandis forest supports indigenous bird's-nest ferns ( $A s-$ plenium nidus L.) in the canopy and laua'e fern, Phymatosorus scolopendria (Burm.), in the understory. The remainder of the native flora consists primarily of indigenous strand species found on many islands in the Pacific, such as beach heliotrope (Tournefortia argentea L. f.), Scaevola sericea Vahl, and Pandanus tectorius Parkinson. One plant variety is considered endemic to Palmyra: a grass, Lepturus repens (G. Forst.) R. Br. var. palmyrensis, which is found in scattered patches throughout the atoll.

The historical record for terrestrial arthropod species on Palmyra Atoll is sparse. Otto Swezey published a list of 18 taxa, identified at various resolution, collected by Joseph
Rock and Montague Cooke on a 1913 expedition (Swezey 1914). Krauss (1953) reported an additional $70+$ taxa from an expedition in 1948, overlapping minimally with Swezey's list. A comprehensive assessment of the terrestrial arthropod fauna has never been performed, and it is not known whether any native arthropods persist, aside from four species of abundant land crabs-B. latro, Cardisoma carnifex (Herbst.), Coenobita brevimanus Dana, and Coenobita perlatus H. Milne Edwards.

In 2003, we conducted terrestrial arthropod surveys on Palmyra Atoll. The goals of the study were to: (1) compile a current list of terrestrial arthropod species from contemporary sampling; (2) determine probable biogeographic origins or residency status (introduced, indigenous, or endemic) for all taxa; (3) compare these lists with the record from historical expeditions; and (4) assess potential threats to native species and ecosystem integrity. These surveys were necessary to develop a management and conservation plan for the terrestrial resources and biodiversity of Palmyra Atoll. We report an important new threat to $P$. grandis (a facultative mutualism between introduced ants and scale insects), review the literature on this association from other Pacific islands, and provide recommendations for quarantine and conservation.

MATERIALS AND METHODS

\section{Artbropod Surveys}

The terrestrial arthropod fauna was surveyed during two visits to Palmyra (28 March-1 April and 8-18 June 2003), supplemented by subsequent opportunistic collections. Because of the time constraints of the survey expeditions and the remoteness of Palmyra Atoll, we were unable to complete detailed quantitative sampling. Therefore, no attempt was made to quantify population sizes, community structure, or species richness, or define habitat associations and islet distributions of arthropod taxa. The absence of particular taxa does not preclude their presence on the atoll. However, we are confident that the most common and widespread terrestrial ar- 
thropods present on the atoll in 2003 were collected and identified.

Malaise traps, light traps, and blacklighted sheets were used to sample active cursorial and flying arthropods (Southwood and Henderson 2000, Toda and Kitching 2002). Malaise traps were set on Cooper, Eastern, Sand, and South Islets and left in place between 2 and 5 days. A total of eight malaise trap samples was taken in March-April and June 2003. Bucket-type light traps (Bioquip, Inc.) were set overnight on Cooper (2 trap-nights), Dudley, Lesley, Lost, Sand, and South Islets, for a total of 7 trap-nights in June 2003.

Vegetation was sampled using sweep nets and beating sheets and by visual inspection and excavation of leaves, flowers, fruits, branches, and bark. To sample the epigean fauna, several designs of pitfall traps were tested but all failed because of the rapid and pervasive interference of coconut crabs. Soil cores were not taken systematically because of the rocky substrate and lack of soil in many areas. Therefore, we sifted litter and soils onto beating sheets and collected visible arthropods with forceps and aspirators. Ants were sampled by baiting with peanut butter and canned lunch meat, as well as opportunistic collecting and litter sifting.

Most arthropods were collected into 95\% ethanol. Lepidopteran adults collected with lights were killed with ethyl acetate, field mounted when possible, and stored in desiccation chambers. With the aid of specialists (see Acknowledgments) and by reference to historical museum specimens, all taxa were identified to the highest possible taxonomic resolution. For taxa identified to genus or species, biogeographic origins and residency status were inferred from professional communication and the literature (e.g., Nishida 2002).

In addition to the specimens collected during these surveys, we have included specimens collected during focused ant surveys in 2001 and 2004 (M. Richardson, unpubl. data; P. Krushelnycky and P. Lester, unpubl. data), mosquito surveys in 2002 (Depkin 2002), and opportunistic collections between 2003 and 2005 (A.T.H. and M.W.L.). Voucher specimens are deposited at the Bishop Museum and at the University of Hawai' $\mathrm{i}$ Insect $\mathrm{Mu}$ seum (Honolulu, Hawai ${ }^{i}$ ).

\section{RESULTS}

We recognized 113 arthropod taxa from our surveys (Figure 2, Appendix). The majority of taxa were identified to the species level, but some were identifiable only to genus or family. Flies (Diptera, 38 species) were the most species-rich, followed by wasps and ants (Hymenoptera, 20 species), beetles (Coleoptera, 19 species), spiders (Araneae, nine species), hemipterans (including Heteroptera and Homoptera, nine species), crickets and grasshoppers (Orthoptera, six species), and moths (Lepidoptera, six species); the remaining six species belonged to other orders. All beetles and ants were unequivocal historical introductions, but some flies and other taxa could not be identified to species or their biogeographic status could not be determined.

Our current surveys added to taxa reported by historical surveys, bringing the total list to 163 taxa recorded from Palmyra since 1913 (Appendix). Previously, 88 taxa had been recorded (Swezey 1914, Krauss 1953), 68 of which were identified to the species level; of these, at least 32 were recollected (Figure 3), although voucher specimens for some historically collected taxa could not be located to compare with contemporary specimens. Of taxa identified to the species level, 36 species recorded during the two historical surveys were not recollected, and 51 of $87(59 \%)$ were new records for the atoll.

Of the 119 taxa identified to the species level from Palmyra, most (106 taxa, 89\%) are also recorded from the Hawaiian Islands (Nishida 2002). Most of these (99 species, $93 \%$ ) are considered accidental introductions to Hawai'i, whereas only three species (all coccinellid beetles) were purposefully introduced for biological control (Nishida 2002). There is no evidence of intentional introductions to Palmyra; thus all introduced species on Palmyra are considered accidental introductions. The majority of species now recorded from Palmyra Atoll fall into this class $(102 / 119,86 \%)$. 


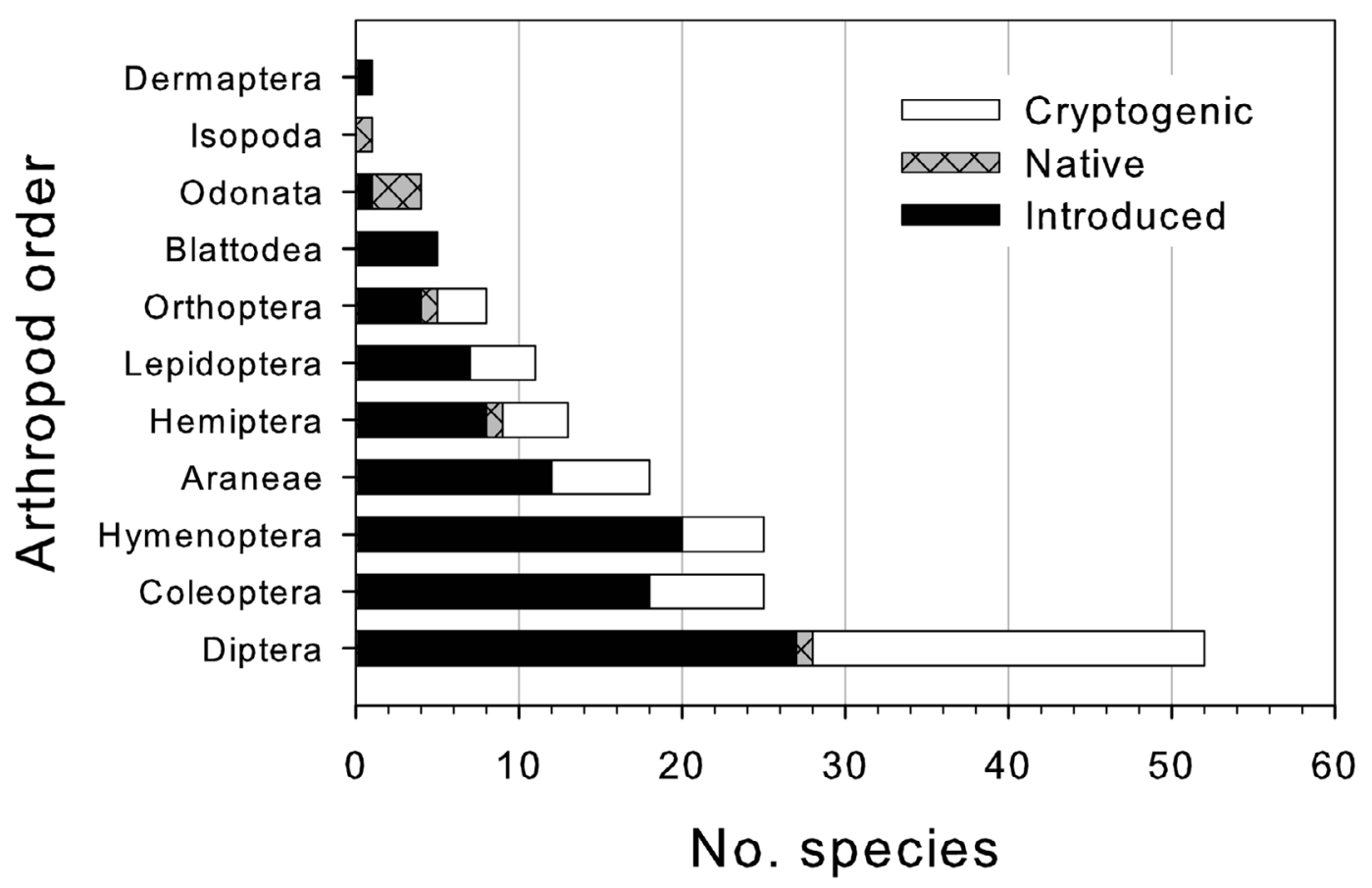

FIGURE 2. Summary of introduced, native, and cryptogenic species richness within arthropod orders from recent collections, 2003-2005.

Only seven contemporary taxa were classified as indigenous species. These include three odonates, Anax junius (Drury), Pantala flavescens (Fabricius), and Ischnura aurora Brauer; a predaceous tettigoniid katydid, Phisis boldhausi Karny; a marine water strider, Halobates micans Eschscholz; a cranefly, Styringomyia didyma Grimshaw; and an isopod, Australophiloscia societatis (Maccagno) (Appendix). All of these species are distributed in the equatorial Pacific and occur naturally in similar habitats on neighboring islands (Walker and Deitz 1979, Jin et al. 1991, Nishida 2002, Evenhuis 2005, Harada 2005). The crambid moth Piletocera signiferalis (Wallengren) is widespread in the Pacific (Clarke 1986) and may be native to Palmyra, but it is unclear to what extent its distribution is natural. Several other taxa are possibly native, but less is known concerning their natural distributions or species-level identifications: two species of dolichopodid flies (Chrysosoma complicatum Becker and Chrysosoma sp. near mo- lestum Parent) and the gryllid cricket in the genus Ornebius. Several possibly indigenous taxa were collected in historical surveys but not recollected during our trips. These include the tetragnathid spider Tetragnatha keyserlingi Simon, the mirid bug Trigonotylus brevipes Jakovlev, the gryllid cricket Speonemobius tigrinus (Saussure), the butterfly Hypolimnas bolina Linnaeus (Nymphalidae), and the flies Dasyrbicnoessa insularis (Aldrich), Nocticanace marshallensis Wirth, Chrysotus javanensis de Meijere, and Olfersia aenescens Thomson.

\section{DISCUSSION}

\section{Introduced Invertebrates}

Although the true extent of native biodiversity before human arrival on Palmyra will never be known, the contemporary terrestrial invertebrate fauna is dominated by introduced species. The great majority of the recorded species are accidentally or purpose- 


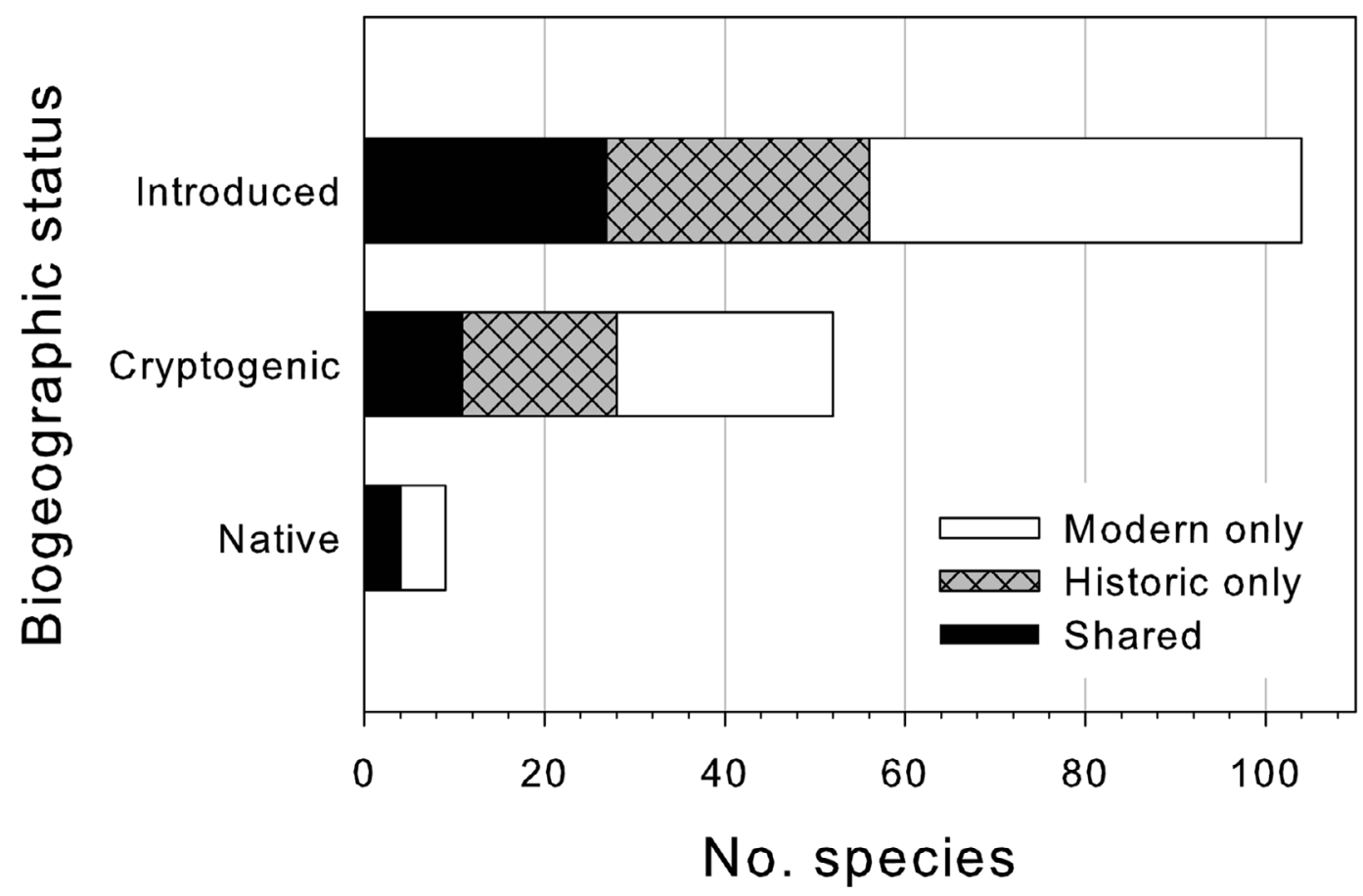

FIGURE 3. Species richness of introduced, native, and cryptogenic arthropods collected only in historical $(1913,1948)$ and recent (2003-2005) collections, and in both sampling periods (shared species). Uncertain historical natives $(n=8$, Appendix) are classified as cryptogenic.

fully introduced species also reported from the Hawaiian Islands (106/119, 89\% [Nishida 2002]). Thus, we suggest that Hawai'i was the predominant historical source of exotic arthropod propagules, most likely during the period of heavy military occupation and transit (1938-1961). Military installations have been blamed for other introductions of pestiferous tramp species to Hawai'i during that time period (e.g., Argentine ant, Linepithema bumile [Zimmerman 1941]), and Hawai'i has always been the dominant shipping connection to Palmyra Atoll (Dawson 1959).

Krauss (1953) reported almost no overlap of the 70+ taxa encountered in 1948 with those recorded during the surveys reported by Swezey (1914) — the earwig Euborellia annulipes (Lucas) was the only species confirmed from both surveys. Our recent collections show a somewhat higher ratio of overlap with previous collections (Figure 3). This may re- flect the greater comprehensiveness of our recent assessments, or it may suggest that the introduction rate has tailed off since the peak of human activity (i.e., military occupation) ceased in 1961. Still, there was a surprising degree of nonoverlap between our collections and species lists from Swezey (1914) and Krauss (1953). Of the 87 identified species we collected, $52(63 \%)$ were not recorded in historical surveys.

No species were clearly endemic to Palmyra (Appendix), but because any endemic species would be undescribed, it remains possible that endemic species exist among the specimens not identified to the species level. Nevertheless, invasive arthropod species dominated the atoll in terms of overall richness and qualitative abundance. For most of these species, there is little information on their effects on native species or ecosystem function. However, two groups of invasive insects 
that were particularly abundant, with welldocumented impacts on native vegetation (ants and hemipteran phloem-feeding insects) are discussed here.

\section{The Pisonia-Pulvinaria-Pheidole Problem}

The terrestrial habitats of Palmyra are valued for conservation because the atoll features some of the largest remaining stands of P. grandis forest (Wester 1985, MuellerDombois and Fosberg 1998). Pisonia grandis occurs primarily on small islands throughout the tropical Indo-Pacific where seabirds nest (St. John 1951, Airy-Shaw 1952, Stemmerik 1964, Mueller-Dombois and Fosberg 1998, Burger 2005). The distribution of $P$. grandis is usually attributed to both the spread of seeds stuck to the feathers of seabirds and growth facilitated by bird guano (Airy-Shaw 1952, Stemmerik 1964, Burger 2005). As the dominant native tree on Palmyra, $P$. grandis is a characterizing feature of the terrestrial ecosystem and provides nesting and roosting sites for seabirds, especially white terns, Gygis alba (Sparrman), and black noddies, Anous minutus Boie. Walker (1991a) found that the size of breeding colonies of black noddies was positively associated with the areal extent and maximum height of $P$. grandis stands on Great Barrier Reef islands. The height of the canopies may provide protection from introduced black rats, which can prey on adult birds and nestlings (Stapp 2002). Moreover, these forests on coralline substrates, in combination with the high densities of nesting seabirds, create a phosphate-rich humic soil substrate not otherwise found on oceanic cays and atolls (Walker 1991a, MuellerDombois and Fosberg 1998). A healthy stand tends to contain limited understory growthand invasion by nonindigenous plantsbecause the broad-leaved, tall canopy prevents most light from reaching the forest floor.

Pisonia grandis stands throughout their range are disappearing quickly because of anthropogenic habitat destruction and human-induced infestations by nonnative insects (Mueller-Dombois and Fosberg 1998,
Kay et al. 2003). Repeated defoliation events and eventual death of many large trees have been observed since 2003 (Figure 4). Concurrent with these defoliation events, the estimated spatial extent of healthy $P$. grandis stands decreased more than $30 \%$ from 2002 to 2005 , and the stands were increasingly fragmented (Figure 5) (A. Wegmann, unpubl. data). Currently, numerous invading invertebrates may be acting synergistically to threaten the viability of the $P$. grandis population on Palmyra Atoll. Quantitative data are needed to unambiguously ascribe causes and effects; here, we document the resident arthropod species and review the literature pertinent to this phenomenon.

At least 10 species of ants were found in recent surveys, the most notorious of which are the African big-headed ant, Pheidole megacephala (Fabricius); crazy ants Paratrechina bourbonica (Forel) and P. vaga (Forel); and the Guinea ant, Tetramorium bicarinatum (Nylander). Ants were present in high densities throughout the atoll, but $\mathrm{Ph}$. megacephala was the dominant species on most islets. On islets where $P h$. megacephala was not found, T. bicarinatum and Paratrechina bourbonica were the local dominant species. Introduced ants and other social insects (e.g., paper wasp Polistes aurifer Saussure) can be devastating generalist predators of native insects on oceanic islands where native social insects are depauperate or entirely lacking (Cole et al. 1992, Wilson 1996, Gerlach 2004, Krushelnycky et al. 2005, Le Breton et al. 2005).

In 2003, we observed these ants farming an unrecorded scale insect, Pulvinaria urbicola (Cockerell \& Parrott), on P. grandis leaves. Although unidentified at the time, an outbreaking insect was observed on $P$. grandis in close association with ants as early as August 2001 (Depkin 2002). By March 2002, Depkin reported that mature trees infested with these insects on one of Palmyra's larger islets (Eastern) had lost $>50 \%$ of their leaves. Nest loss of seabirds using $P$. grandis for breeding purposes in the infested zones was described in the report as an indirect effect of the scale infestation due to weakened 


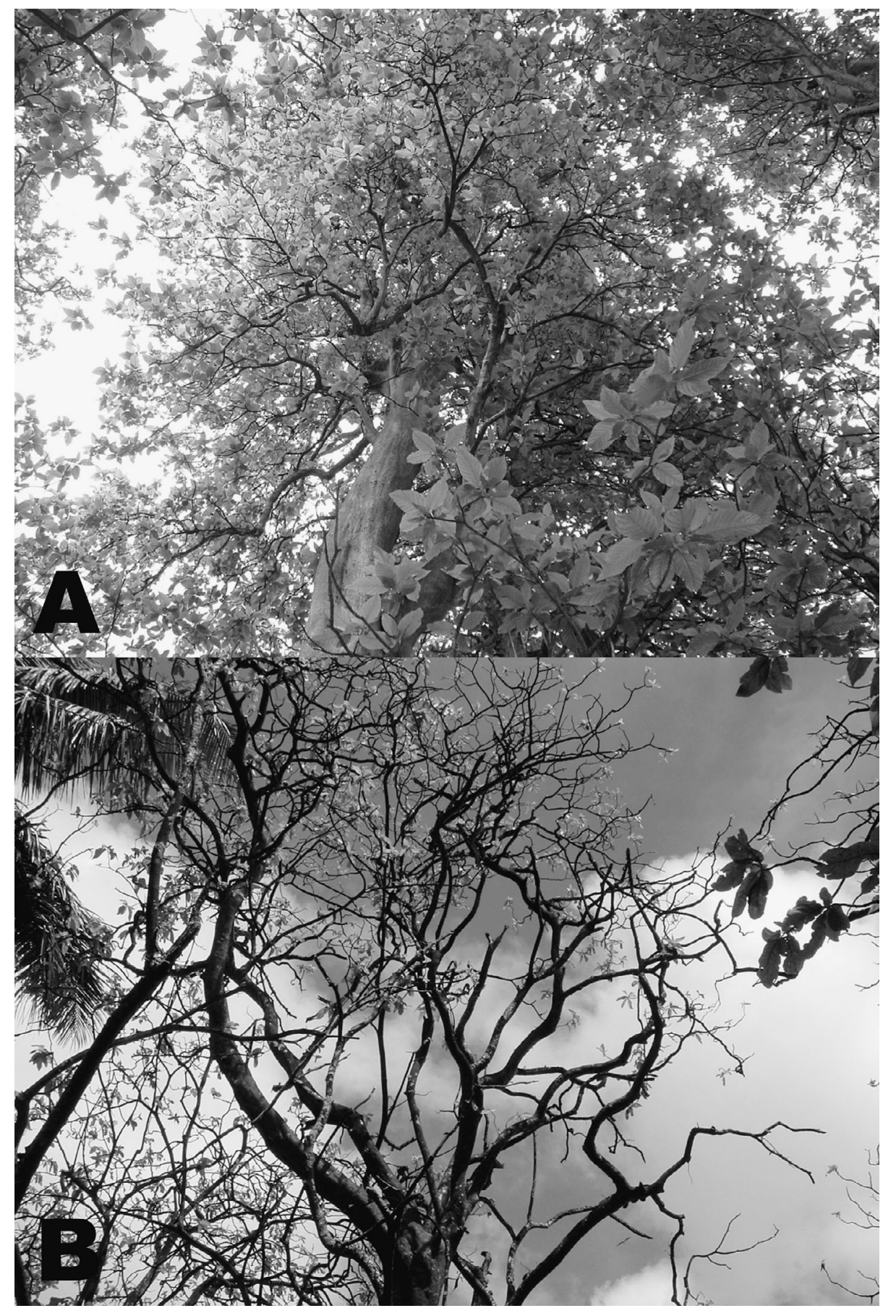

Figure 4. (A) Healthy Pisonia grandis, and (B) Pisonia grandis infested with Pulvinaria urbicola (photos by A.T.H. in June 2003). 
Pisonia Forest 2002

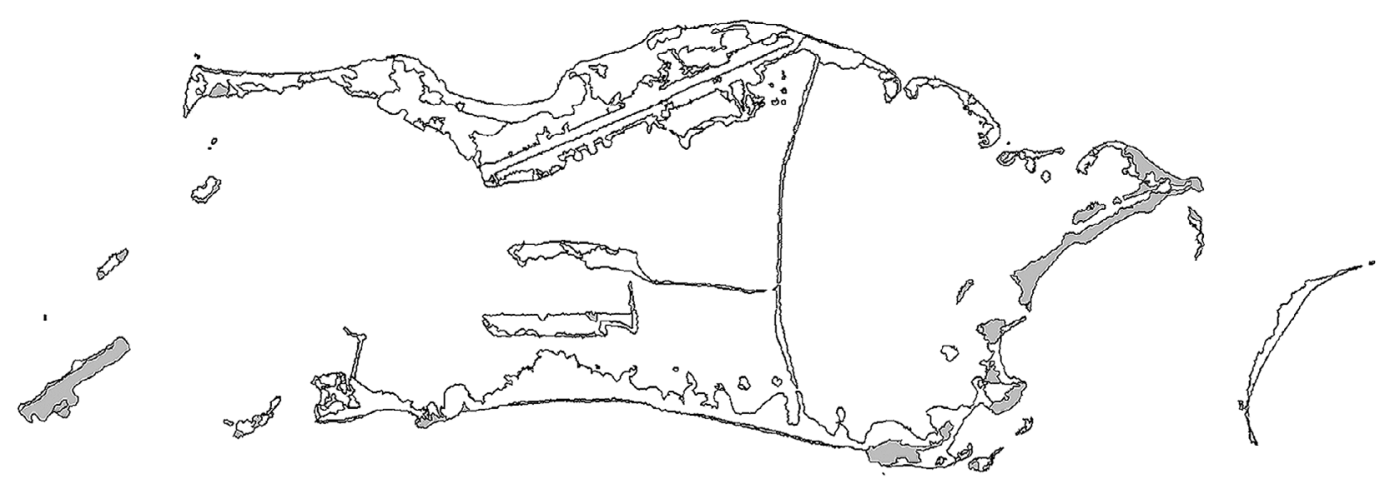

Pisonia Forest 2005

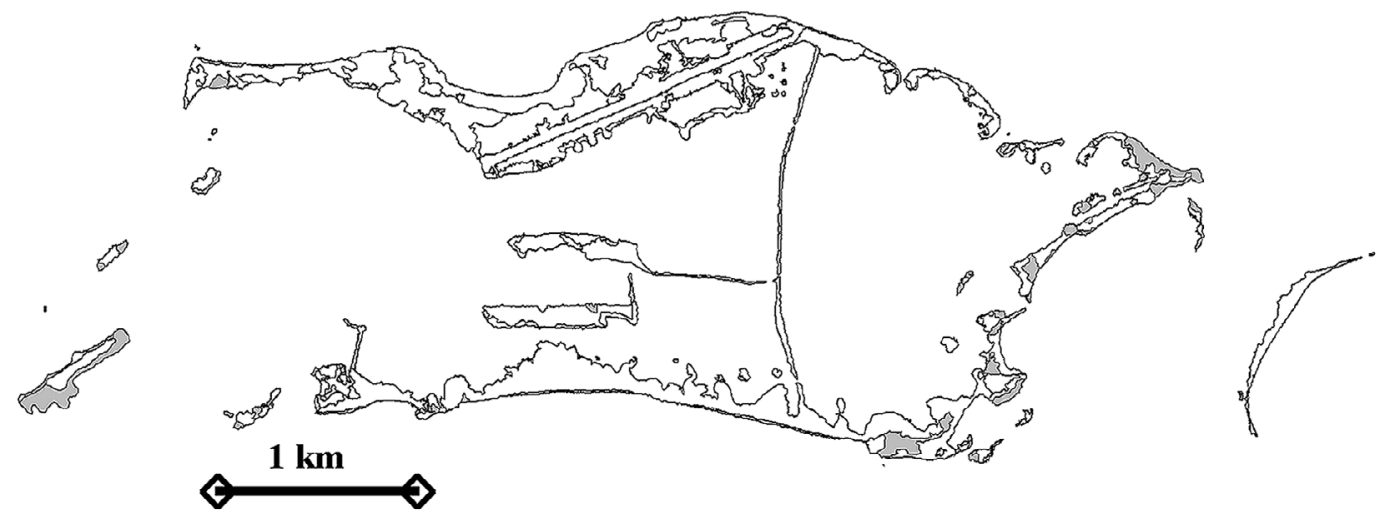

Figure 5. Extent of vegetated ground area covered by Pisonia grandis on Palmyra Atoll in 2002 and 2005. In 2002, P. grandis covered approximately $12 \%$ of vegetated land area $(27.3 \mathrm{ha})$. The percentage was approximately $8 \%$ in 2005 (18.2 ha). Data and figure are courtesy of Alex Wegmann.

branches (Depkin 2002). Higher rates of $P$. grandis deadfall were also noted in infested stands, and areas that had been fully shaded by these trees in 2001 were exposed to direct sunlight 1 yr later (Depkin 2002).

Pulvinaria urbicola is a widespread pest of solanaceous crops that has been implicated in the poor health and dieback of $P$. grandis stands throughout the Indo-Pacific region. In the Seychelles, stress caused by Pu. urbicola scales tended by the long-legged ant, Anoplolepis gracilipes (F. Smith), caused defoliation and death of mature trees (Hill et al. 2003). On multiple islands on the Great Barrier
Reef of Australia, green scales tended by $P h$. megacephala have locally extirpated mature $P$. grandis stands, leading to dramatic shifts from closed canopy to open scrub (Olds et al. 1996, Smith and Papacek 2001, Kay et al. 2003). Pulvinaria urbicola also has been linked to poor health and dieback of $P$. grandis trees on Rose Atoll in American Samoa (J. Burgett, pers. comm.).

Because there have been very few invertebrate assessments for Palmyra, the local history of this ant-scale association is not well known. However, ants have been in Palmyra for at least a century. Tetramorium bicarina- 
tum was reported as "very abundant" on the atoll in the early 1900s (Swezey 1914), and Pheidole megacephala (recorded as Pheidole sp. but presumed to be $P$ h. megacephala) invaded before 1948 (Krauss 1953). It is probable that other introduced ant species were present but uncollected during those surveys. However, because of its ecological dominance in numerous habitats globally and as observed on Palmyra Atoll (e.g., Illingworth 1927, Hoffman et al. 1999), it is unlikely that $\mathrm{Ph}$. megacephala was overlooked if present during Swezey's survey. The scale insect $P u$. urbicola was not recorded in either of the previous surveys on the atoll, and its negative effects on the $P$. grandis forest have been noted only recently. In light of this information, we propose that Pu. urbicola is a recent introduction to Palmyra Atoll.

Introduced natural enemies can be a viable means of control for pestiferous arthropods (Hajek 2004), and several parasitoid species used for Pulvinaria spp. control in other locations (Smith and Papacek 2001) were collected in our surveys. We collected the aphelinid wasps Coccophagus ceroplastae (Howard) and Euryischomyia flavithorax Girault \& Dodd and the encytrid wasp Metaphycus flavus (Howard), which are all known to include Pulvinaria spp. in their host ranges. Several coccinellid beetle species also occur on Palmyra, including Coelophora inaqualis (Fabricius), Diomus notescens (Blackburn), and Rhyzobius lophanthae (Blaisdell). However, these insects were relatively uncommon, wasp parasitism rates were quite low (mean exit holes per insect on Eastern Islet = $2.1 \% \pm 0.7$ S.E. [Krushelnycky and Lester, unpubl. data]), and Pu. urbicola does not appear to be under control. Smith and Papacek (2001) advocated the release of Cryptolaemus montrouzieri Mulsant to augment the presence of the parasitic wasp C. ceroplastae in the Coringa-Herald National Nature Reserve in the Coral Sea. They argued that parasitoid wasps can regulate scales at low densities, but outbreaks must be controlled with augmentative releases of generalist predators.

Ants in general, and $\mathrm{Ph}$. megacephala specifically, often interfere with other natural en- emies of Hemiptera used in biological control (Reimer et al. 1993, Jahn and Beardsley 1994, 2000, Helms and Vinson 2002, Lach 2003). Ants form facultative mutualisms with mealybugs, scales, aphids, planthoppers, and other hemipterans by protecting them from predators and parasitoids and moving them among individual host plants while harvesting honeydew, the sugary exudate upon which the ants feed (Buckley 1987). Thus, both ant and scale densities can reach higher population levels than either species could attain in isolation, with devastating effects on host plants and vegetation structure (O'Dowd et al. 2003). Pheidole megacephala also attended thick aggregations of Dysmicoccus neobrevipes Beardsley (Pseudococcidae) around the fruits of the rare indigenous tree Ochrosia oppositifolia (Lam.) K. Schum. The cottony-cushion scale (Icerya purchasi Maskell) and an unidentified sooty mold (Capnodiaceae) were observed on Sceavola sericea, and sooty mold commonly grew on laua'e fern (Phymatosorus scolopendri) under $P$. grandis canopies infested with $P u$. urbicola. The opaque coating of sooty molds on plant surfaces, encouraged by the rich sugar content of hemipteran honeydew "rain" (Wood et al. 1988), can reduce light interception and photosynthesis, thus increasing stress on recipient plants (Fokkema et al. 1983).

\section{CONCLUSIONS}

Despite the fact that the flora and fauna of Palmyra have already been overwhelmed by nonnative species, globally important stands of $P$. grandis and dependent seabird populations remain. Yet the atoll remains highly susceptible to new introductions of invasive species. This is clearly demonstrated by the recent decline of $P$. grandis, which we propose is caused by recent introductions of scale insects and accelerated by ants. Hawai'i accumulates 20-30 new foreign insect species per year (Beardsley 1962), and the small island of Guam receives 12-15 new species (Schreiner and Nafus 1986), many of which become important pests to agriculture and native species. Even with the extremely limited human 
transit to Palmyra, more recent introductions continue.

Indeed, a new unidentified whitefly in the family Aleyrodidae (Hemiptera) was discovered on the atoll in 2005, and it quickly reached nuisance levels on Scaevola species and other native plants on Cooper Islet. The research field station, housing, and airplane runway are located on Cooper; therefore a majority of the current human traffic and impact on Palmyra Atoll is concentrated on that particular islet. The family Aleyrodidae has not previously been recorded from Palmyra, either by ourselves or in previous surveys (note that the insect referred to as a "whitefly" by Depkin [2002] proved to be the scale insect Pu. urbicola, not a true whitefly). In less than $2 \mathrm{yr}$, this presumably recent introduction has gone from being absent or undetectable to a major nuisance, with predicted negative impacts on the native flora (Byrne and Bellows 1991).

In response to $P h$. megacephala and $P u$. urbicola infestations in the $P$. grandis forests of the Capricorn Cays National Park of Queensland, Australia, Kay et al. (2003) recommended strategies to fight these infestations, including (1) annual censuses of habitats to monitor infestation levels, (2) implementation of a biocontrol program using the ladybird beetle Cryptolaemus montrouzieri and parasitoid wasps in combination with ant control measures, and (3) development and implementation of an integrated revegetation and weed control program. In light of this ant-scale infestation on Palmyra and the declining $P$. grandis, we recommend the continued implementation of control measures for both ants and scales, which are currently ongoing. More experimental data are urgently needed to determine the individual and combined effects of ants and scales on P. grandis at this location. Generally, introduction of new biological control measures (e.g., Cryptolaemus montrouzieri) should proceed with the utmost caution, to avoid nontarget impacts and other documented pitfalls (e.g., Pearson and Callaway 2003, Simberloff 2005). In the current case, nontarget impacts of specialized natural enemies are less likely because all in- sects collected from the hemipteran suborder Sternorrhyncha were unequivocal introduced species. Of course, all mitigation and control measures should be accompanied with monitoring measures to assess the efficacy of treatments and to test the causal mechanisms proposed in this paper. In the near term, a viable option would be to propagate $P$. grandis saplings in greenhouses protected from ants and scales. Even after the destructive impacts of mining and goat grazing, $P$. grandis is capable of repopulating an area after substantial disturbances (Elsol 1985, Walker 1991b) if pestiferous impacts can be minimized. However, this task will be more difficult if a complete phase shift to coconut palms or open scrubland has already occurred (Kay et al. 2003).

Moreover, effective management protocols for Palmyra Atoll should include an enforceable quarantine policy. Primary pathways of transmission of invasive species include hitchhiking on cargo in transit such as fresh produce, plants, and packing material (Reichard and White 2001). These items should be inspected in detail, and high-risk categories (i.e., live plants) should be completely prohibited from transport to Palmyra. In addition, docking recreational craft should be scrutinized for the possibility of infestation by ants or plant pathogens and pests. Because traffic to and from the atoll is relatively limited, implementation of a robust quarantine policy, in which all cargo is thoroughly inspected or treated, should be feasible.

\section{ACKNOWLEDGMENTS}

We thank the Bishop Museum for access to collections and working space. Thanks also to Keith Arakaki, Joe Beatty, Ron Englund, Neal Evenhuis, Michael Gates, Tino Gonsalves, Bertram Lindsey, Gary Miller, John Noyes, Dan Polhemus, Neil Reimer, and G. Allan Samuelson for identification and verification of insect specimens. Nathan Sanders, Robert Cowie, Phil Lester, and two anonymous reviewers provided critical comments on the manuscript, and Stephanie Dunbar, Paul Krushelnycky, Alex Wegmann, Zenneth 
Compania, Frank Lau, Emilia Wiggins, Jessica Rodrigues, Mari Oishi, Alex Duffy, and Elizabeth Lange assisted on the ground. Special thanks are due Alex Wegmann for providing the data and map for Figure 5 .

\section{Literature Cited}

Airy-Shaw, H. K. 1952. On the distribution of Pisonia grandis R. Br. (Nyctaginaceae), with special reference to Malaysia. Kew Bull. 7:87-97.

Anonymous. 1998. Draft environmental assessment for the proposed Palmyra Atoll National Wildlife Refuge, Line Islands, Central Pacific Ocean. U.S. Fish and Wildlife Service, Honolulu, Hawai'i.

Beardsley, J. W., Jr. 1962. On accidental immigration and establishment of terrestrial arthropods in Hawaii during recent years. Proc. Hawaii. Entomol. Soc. 18:99-109.

Buckley, R. 1987. Ant-plant-homopteran interactions. Adv. Ecol. Res. 16:53-85.

Burger, A. E. 2005. Dispersal and germination of seeds of Pisonia grandis, an IndoPacific tropical tree associated with insular seabird colonies. J. Trop. Ecol. 21:263271.

Byrne, D. N., and T. S. Bellows Jr. 1991. Whitefly biology. Annu. Rev. Entomol. 36:431-457.

Carlquist, S. 1974. Island biology. Columbia University Press, New York.

Chauvet, C., and T. Kadiri-Jan. 1999. Assessment of an unexploited population of coconut crabs, Birgus latro (Linne, 1767), on Taiaro atoll (Tuamoto Archipelago, French Polynesia). Coral Reefs 18:297299.

Clarke, J. F. G. 1986. Pyralidae and microlepidoptera of the Marquesas Archipelago. Smithson. Contrib. Zool. 416.

Cole, F. R., A. C. Medeiros, L. L. Loope, and W. W. Zuehlke. 1992. Effects of the Argentine ant on arthropod fauna of Hawaiian high-elevation shrubland. Ecology 73:1313-1322.

Cowie, R. H. 2001. Decline and homogenization of Pacific faunas: The land snails of American Samoa. Biol. Conserv. 99:207222.
D'Antonio, C. M., and T. L. Dudley. 1995. Biological invasions as agents of change on islands versus mainlands. Pages 103121 in P. M. Vitousek, H. Andersen, and L. L. Loope, eds. Islands: Biodiversity and ecosystem function. Springer-Verlag, Berlin.

Dawson, Y. E. 1959. Changes in Palmyra Atoll and its vegetation through the agency of man, 1913-1958. Pac. Nat. 1:1-51.

Depkin, C. D. 2002. Trip report to Palmyra Atoll, 06 August 2001-07 October 2002. U.S. Fish and Wildlife Service, Honolulu, Hawai'i.

Elsol, J. A. 1985. Vegetation of an eastern Australian coral cay-Lady Musgrave Island. Proc. R. Soc. Queensl. 96:33-48.

Evenhuis, N. L. 2005. Preliminary checklist of the Tipuloidea (Diptera) of Fiji, with new combinations. Bishop Mus. Occas. Pap. 82:27-30.

Fokkema, N. J., I. Riphagen, R. J. Poot, and C. de Jong. 1983. Aphid honeydew, a potential stimulant of Cochliobolus satirus and Septoria nodorum and the competitive role of saprophytic mycoflora. Trans. Br. Mycol. Soc. 81:355-363.

Gerlach, J. 2004. Impact of the invasive crazy ant Anoplolepis gracilipes on Bird Island, Seychelles. J. Insect Conserv. 8:15-25.

Hajek, A. E. 2004. Natural enemies: An introduction to biological control. Cambridge University Press, Cambridge, United Kingdom.

Harada, T. 2005. Geographical distribution of three oceanic Halobates spp. and an account of the behaviour of $H$. sericeus (Heteroptera: Gerridae). Eur. J. Entomol. 102:299-302.

Helms, K. R., and S. B. Vinson. 2002. Widespread association of the invasive ant Solenopsis invicta with an invasive mealybug. Ecology 83:2425-2438.

Hill, M., K. Holm, T. Vel, N. J. Shah, and P. Matyot. 2003. Impact of the yellow crazy ant Anoplolepis gracilipes on Bird Island, Seychelles. Biodiv. Conserv. 12:19691984.

Hoffman, B. D., A. N. Andersen, and G. J. E. Hill. 1999. Impact of an introduced ant on native rain forest invertebrates: Pheidole 
megacephala in monsoonal Australia. Oecologia (Berl.) 120:595-604.

Illingworth, J. F. 1927. Predominance of Pheidole megacephala (Fab.) (Hymenoptera). Proc. Hawaii. Entomol. Soc. 6:389390.

IUCN. 2004. IUCN Red list of threatened species. http://www.iucnredlist.org/ (date accessed: 21 January 2006).

Jahn, G. C., and J. W. Beardsley. 1994. Bigheaded ants, Pheidole megacephala: Interference with biological control of gray pineapple mealybugs. Pages 199-205 in D. F. Williams, ed. Exotic ants: Biology, impact, and control of introduced species. Westview, Boulder, Colorado.

- 2000. Interactions of ants (Hymenoptera: Formicidae) and mealybugs (Homoptera: Pseuodococcidae) on pineapple. Proc. Hawaii. Entomol. Soc. 34:181185.

Jin, X. B., D. K. M. Kevan, and T. C. Hsu. 1991. A new species of small predacious orthopteroid Paraphisis spinicercis from Papua New Guinea (Grylloptera: Tettigonioidea). Zhonghua Kunchong 11:5964.

Kay, A., J. Olds, R. Elder, K. Bell, J. Platten, R. Charles, K. Mulville, M. Crossman, S. Crocetti, and R. White. 2003. The impact and distribution of the soft scale Pulvinaria urbicola in the Pisonia grandis forests of the Capricornia Cays national parks. Queensland Parks and Wildlife Service internal report, Queensland, Australia.

Krauss, N. L. H. 1953. Insects and other invertebrates from Palmyra Atoll and Christmas Island. Proc. Hawaii. Entomol. Soc. 15:217-220.

Krushelnycky, P. D., L. L. Loope, and N. J. Reimer. 2005. The ecology, policy, and management of ants in Hawaii. Proc. Hawaii. Entomol. Soc. 37:1-25.

Lach, L. 2003. Invasive ants: Unwanted partners in ant-plant interactions. Ann. Mo. Bot. Gard. 90:91-108.

Le Breton, J., H. Jourdan, J. Chazeau, J. Orivel, and A. Dejean. 2005. Niche opportunity and ant invasion: The case of Wasmannia auropunctata in a New Caledonian rain forest. J. Trop. Ecol. 21:93-98.
Mack, R. N., D. Simberloff, W. M. Lonsdale, H. Evans, M. Clout, and F. A. Bazzaz. 2000. Biotic invasions: Causes, epidemiology, global consequences, and control. Ecol. Appl. 10:689-710.

Mueller-Dombois, D., and F. R. Fosberg. 1998. Vegetation of the tropical Pacific islands. Springer, New York.

Nishida, G. M., ed. 2002. Hawaiian terrestrial arthropod checklist. 4th ed. Bishop Museum Press, Honolulu, Hawai'i.

O’Dowd, D. J., P. T. Green, and P. S. Lake. 2003. Invasional 'meltdown' on an oceanic island. Ecol. Lett. 6:812-817.

Olden, J. D., N. L. Poff, M. R. Douglas, M. E. Douglas, and K. D. Fausch. 2004. Ecological and evolutionary consequences of biotic homogenization. Trends Ecol. Evol. 19:18-24.

Olds, J. A., R. J. Elder, R. M. Charles, J. R. Platten, and K. L. Bell. 1996. Pulvinaria urbicola (Cockerell) on Pisonia grandis at Tryon Island, Great Barrier Reef (abstract). Page 197 in The Great Barrier Reef: Science, use and management: Proceedings from a National Conference. Great Barrier Reef Marine Park Authority, Townsville, Australia.

Pearson, D. E., and R. M. Callaway. 2003. Indirect effects of host-specific biological control agents. Trends Ecol. Evol. 18: 456-461.

Reichard, S. H., and P. White. 2001. Horticulture as a pathway of invasive plant introductions in the United States. BioScience 51:103-113.

Reimer, N. J., M.-L. Cope, and G. Yasuda. 1993. Interference of Pheidole megacephala (Hymenoptera: Formicidae) with biological control of Coccus viridus (Homoptera: Coccidae) in coffee. Environ. Entomol. 22:483-488.

Reyne, A. 1939. On the food habits of the coconut crab (Birgus latro), with notes on its distribution. Arch. Neerl. Zool. 3:283320.

Samways, M. J. 1999. Translocating fauna to foreign lands: Here comes the Homogenocene. J. Insect Conserv. 3:65-66.

Sax, D. F., and S. D. Gaines. 2003. Species diversity: From global decreases to local 
increases. Trends Ecol. Evol. 18:561566.

Schreiner, I., and D. Nafus. 1986. Accidental introductions of insect pests to Guam, 1945-1985. Proc. Hawaii. Entomol. Soc. 27:45-72.

Simberloff, D. 2005. The politics of assessing risk for biological invasions: The USA as a case study. Trends Ecol. Evol. 20:216222.

Smith, D., and D. Papacek. 2001. Report on the levels of the scale insect Pulvinaria urbicola and its natural enemies on Pisonia grandis in the Coringa-Herald National Nature Reserve 16-23 March 2001. http://www.deh.gov.au/coasts/mpa/ coringa/insect-1/ (date accessed: 1 August 2005).

Southwood, T. R. E., and P. A. Henderson. 2000. Ecological methods. 3rd ed. Blackwell Science Ltd., London.

Stapp, P. 2002. Stable isotopes reveal evidence of predation by ship rats on seabirds on the Shiant Islands, Scotland. J. Appl. Ecol. 39:831-840.

Stemmerik, J. F. 1964. Nyctaginaceae. Flora Melasiana Ser. 6:450-468.

St. John, H. 1951. The distribution of Pisonia grandis (Nyctaginaceae). Pacific Plant Studies No. 10. Webbia 8:225-228.

Swezey, O. H. 1914. Insects from Palmyra Islands. Proc. Hawaii. Entomol. Soc. 3:1516.

Toda, M., and R. L. Kitching. 2002. Forest ecosystems. Pages 27-109 in T. Nakashizuka and N. E. Stork, eds. Biodiversity re- search methods: IBOY in western Pacific and Asia. Kyoto University Press, Kyoto.

Vitousek, P. M., C. M. D'Antonio, L. L. Loope, and R. Westbrooks. 1999. Biological invasions as global environmental change. Am. Sci. 84:468-478.

Walker, A. K., and L. L. Deitz. 1979. A review of entomophagous insects in the Cook Islands. N. Z. Entomol. 7:70-82.

Walker, T. A. 1991a. Pisonia islands of the Great Barrier Reef. I. The distribution, abundance and dispersal by seabirds of $\mathrm{Pi}$ sonia grandis. Atoll Res. Bull. 350:1-23.

- 1991b. Pisonia islands of the Great Barrier Reef. III. Changes in the vascular flora of Lady Musgrave Island. Atoll Res. Bull. 350:31-41.

Wester, L. 1985. Checklist of the vascular plants of the northern Line Islands. Atoll Res. Bull. 287:1-38.

Whittaker, R. J. 1998. Island biogeography: Ecology, evolution and conservation. Oxford University Press, Oxford, United Kingdom.

Wilson, E. O. 1996. Hawaii: A world without social insects. Bishop Mus. Occas. Pap. $45: 3-7$.

Wood, B. W., W. L. Tedders, and C. C. Reilly. 1988. Sooty mold fungus on pecan foliage suppresses light penetration and net photosynthesis. HortScience 23:851853.

Zimmerman, E. C. 1941. Argentine ant in Hawaii. Proc. Hawaii. Entomol. Soc. 11:108. 
Appendix

Taxonomic List of Terrestrial Arthropod Species Collected from Palmyra Atoll in Historical (Swezey 1914, Krauss 1953) and Recent (2001-2005) Collections

\begin{tabular}{|c|c|c|c|c|c|c|}
\hline \multirow[b]{2}{*}{ Family } & \multirow[b]{2}{*}{$\operatorname{Taxa}^{a}$} & \multirow[b]{2}{*}{ Origin $^{b}$} & \multicolumn{3}{|c|}{ Collections $^{c}$} & \multirow[b]{2}{*}{ Determiner ${ }^{c}$} \\
\hline & & & 1913 & 1948 & $\begin{array}{c}2001- \\
2005\end{array}$ & \\
\hline \multicolumn{7}{|l|}{ Order Araneae } \\
\hline Agelenidae & Agelenidae G. sp. & $?$ & - & $\sqrt{ }$ & - & \\
\hline Araneidae & Neoscona theisi (Walckenaer, 1841) & Intr & - & $\sqrt{ }$ & $\sqrt{ }$ & DG \& JB \\
\hline Heteropodidae & Heteropoda venatoria (Linnaeus, 1767 ) & Intr & - & $\sqrt{ }$ & $\sqrt{ }$ & $\mathrm{JB}$ \\
\hline Pholcidae & Smeringopus pallidus (Blackwall, 1856) & Intr & - & $\sqrt{ }$ & $\sqrt{ }$ & DG \& JB \\
\hline \multirow{8}{*}{ Salticidae } & Hasarius adansoni (Audouin, 1826) & Intr & - & $\sqrt{ }$ & $\sqrt{ }$ & $\mathrm{JB}$ \\
\hline & Menemerus bivittatus (Dufour, 1831) & Intr & - & $\sqrt{ }$ & $\sqrt{ }$ & $\mathrm{JB}$ \\
\hline & Messua cf. felix (Peckham \& Peckham, 1901) & Intr & - & $\sqrt{ }$ & $\sqrt{ }$ & $\mathrm{JB}$ \\
\hline & Phintella versicolor (C. L. Koch, 1846) & $?$ & - & - & $\sqrt{ } *$ & $\mathrm{JB}$ \\
\hline & Plexippus parkulli (Audouin, 1826) & Intr & - & $\sqrt{ }$ & - & \\
\hline & Salticidae G. sp. 1 & $?$ & - & ? & $\sqrt{ }$ & \\
\hline & Salticidae G. sp. 2 & ? & - & ? & $\sqrt{ }$ & \\
\hline & Sandalodes sp. & ? & - & $\sqrt{ }$ & - & \\
\hline \multirow[t]{2}{*}{ Scytodidae } & Scytodes longipes Lucas, 1845 & Intr & - & $\sqrt{ }$ & - & \\
\hline & Scytodes striatipes (L. Koch, 1872) & Intr & - & $\sqrt{ }$ & - & \\
\hline Tetragnathidae & Tetragnatha keyserlingi Simon, 1890 & Nat? & - & $\sqrt{ }$ & - & \\
\hline \multirow[t]{3}{*}{ Theridiidae } & Coleosoma floridanum Banks, 1900 & Intr & - & $\sqrt{ }$ & - & \\
\hline & Latrodectus geometricus C. L. Koch, 1841 & Intr & - & $\sqrt{ }$ & - & \\
\hline & Nesticodes rufipes (Lucas, 1846) & Intr & - & $\sqrt{ }$ & - & \\
\hline \multicolumn{7}{|l|}{ Order Blattodea } \\
\hline Blaberidae & Pycnoscelus indicus (Fabricius, 1775) & Intr & - & - & $\sqrt{ }^{*}$ & DG \\
\hline Blatellidae & Supella longipalpa (Fabricius, 1798) & Intr & - & - & $\sqrt{ }{ }^{*}$ & DG \\
\hline \multirow[t]{3}{*}{ Blattidae } & Periplaneta americana (Linnaeus, 1758) & Intr & - & $\sqrt{ }$ & - & \\
\hline & Periplaneta australasiae (Fabricius, 1775) & Intr & - & $\sqrt{ }$ & $\sqrt{ }$ & DG \\
\hline & Platyzosteria soror (Brunner, 1865) & Intr & - & $\sqrt{ }$ & - & \\
\hline \multicolumn{7}{|l|}{ Order Coleoptera } \\
\hline \multirow[t]{2}{*}{ Anthribidae } & Araecerus vieillardi (Montrouzier, 1860) & Intr & - & - & $\sqrt{ }^{*}$ & GAS \\
\hline & Mauia subnotatus (Boheman, 1859) & Intr & - & - & $\sqrt{ }^{*}$ & GAS \\
\hline Carabidae & Carabidae G. sp. & $?$ & - & $\sqrt{ }$ & $\sqrt{ }$ & GAS \\
\hline \multirow[t]{2}{*}{ Cerambycidae } & Cerambycidae G. sp. 1 & $?$ & - & - & $\sqrt{ }{ }^{*}$ & GAS \\
\hline & Cerambycidae G. sp. 2 & ? & - & - & $\sqrt{ }{ }^{*}$ & GAS \\
\hline \multirow{4}{*}{ Coccinellidae } & Coccinellidae G. sp. & ? & - & - & $\gamma^{*}$ & GAS \\
\hline & Coelophora inaequalis (Fabricius, 1775) & Intr & - & - & $\sqrt{ }^{*}$ & GAS \\
\hline & Diomus notescens (Blackburn, 1889) & Intr & $?$ & $\sqrt{ }$ & - & \\
\hline & Rhyzobius lophanthae (Blaisdell, 1892) & Intr & $?$ & $\sqrt{ }$ & - & \\
\hline Cryptophagidae & Toramus(?) sp. & $?$ & - & $\sqrt{ }$ & - & \\
\hline Cucujidae & Psammoecus insularis (Sharp, 1885) & Intr & - & - & $\sqrt{ }^{*}$ & GAS \\
\hline \multirow[t]{2}{*}{ Elateridae } & Conoderus pallipes (Eschscholtz, 1829) & Intr & $?$ & $\sqrt{ }$ & $\sqrt{ }$ & GAS \\
\hline & Melanoxanthus melanocephalus (Fabricius, 1781) & Intr & $\sqrt{ }$ & - & - & \\
\hline Hydrophilidae & Dactylosternum abdominale (Fabricius, 1792) & Intr & - & - & $\sqrt{ }^{*}$ & GAS \\
\hline Nitidulidae & Carpophilus bumeralis (Fabricius, 1798) & Intr & - & - & $\sqrt{ }^{*}$ & GAS \\
\hline \multirow{5}{*}{ Oedemeridae } & Eobia bicolor (Fairmaine, 1849) & Intr & - & $\sqrt{ }$ & $\sqrt{ }$ & GAS \\
\hline & Eobia decolor (Fairmaine, 1849) & Intr & - & $\sqrt{ }$ & $\sqrt{ }$ & GAS \\
\hline & Eobia kanack (Fairmaine, 1849) & Intr & $\sqrt{ }$ & - & $\sqrt{ }$ & GAS \\
\hline & Eobia sinensis Gemminger, 1870 & Intr & - & - & $\sqrt{ }^{*}$ & GAS \\
\hline & Sessinia livida (Fabricius, 1775) & Intr & - & - & $\gamma^{*}$ & GAS \\
\hline Pselaphidae & Pselaphidae G. sp. & ? & - & $\sqrt{ }$ & - & \\
\hline Ptilidae & Ptilidae G. sp. & ? & - & $\sqrt{ }$ & $\sqrt{ }$ & GAS \\
\hline Scarabaeidae & Saprosites pygmaeus Harold, 1877 & Intr & - & $\sqrt{ }$ & - & \\
\hline Scolytidae & Xyleborus perforans (Wollaston, 1857) & Intr & - & - & $\sqrt{ }^{*}$ & GAS \\
\hline Staphylinidae & Philonthus discoideus (Gravenhorst, 1802) & Intr & - & - & $\sqrt{ }^{*}$ & GAS \\
\hline
\end{tabular}


Appendix (continued)

\begin{tabular}{|c|c|c|c|c|c|c|}
\hline \multirow[b]{2}{*}{ Family } & \multirow[b]{2}{*}{$\operatorname{Taxa}^{a}$} & \multirow[b]{2}{*}{ Origin $^{b}$} & \multicolumn{3}{|c|}{ Collections $^{c}$} & \multirow[b]{2}{*}{ Determiner $^{d}$} \\
\hline & & & 1913 & 1948 & $\begin{array}{c}2001- \\
2005\end{array}$ & \\
\hline \multicolumn{7}{|l|}{ Order Dermaptera } \\
\hline \multicolumn{7}{|l|}{ Order Diptera } \\
\hline \multirow[t]{2}{*}{ Agromyzidae } & Liriomyza sativae Blanchard, 1938 & Intr & - & - & $\sqrt{ }^{*}$ & KA \\
\hline & Liriomyza sp. & $?$ & - & - & $\sqrt{ }^{*}$ & KA \\
\hline \multirow[t]{2}{*}{ Calliphoridae } & Chrysomya megacephala (Fabricius, 1794) & Intr & - & $\sqrt{ }$ & - & \\
\hline & Lucilia sericata (Meigen, 1826) & Intr & - & $\sqrt{ }$ & $\sqrt{ }$ & KA \\
\hline \multirow[t]{2}{*}{ Canaceidae } & Canaceoides sp. & $?$ & - & - & $\sqrt{ }^{*}$ & KA \\
\hline & Nocticanace marshallensis Wirth & Nat? & - & $\sqrt{ }$ & - & \\
\hline \multirow{2}{*}{ Ceratopogonidae } & Ceratopogonidae G. sp. & $?$ & - & - & $\sqrt{ }^{*}$ & $\mathrm{KA}$ \\
\hline & Dasybelea sp. & ? & - & $\sqrt{ }$ & $\sqrt{ }$ & KA \\
\hline \multirow[t]{2}{*}{ Chironomidae } & Chironomidae G. sp. & ? & - & $\sqrt{ }$ & - & \\
\hline & Clunio sp. & $?$ & - & $?$ & $\sqrt{ }$ & KA \\
\hline \multirow[t]{3}{*}{ Chloropidae } & Cadrema pallida (Loew, 1865) & Intr & - & $\sqrt{ }$ & $\sqrt{ }$ & KA \\
\hline & Gaurax bicoloripes (Malloch, 1933) & Intr & - & - & $\sqrt{ }^{*}$ & KA \\
\hline & Hippelates sp. & $?$ & $\sqrt{ }$ & - & - & \\
\hline \multirow[t]{2}{*}{ Culicidae } & Aedes albopictus (Skuse, 1894) & Intr & - & - & $\sqrt{ }^{* e}$ & GAS \\
\hline & Culex quinquefasciatus Say, 1823 & Intr & - & - & $\sqrt{*_{e}}$ & GAS \\
\hline \multirow[t]{6}{*}{ Dolichopodidae } & Chrysosoma complicatum Becker, 1922 & Intr & - & - & $\sqrt{ }{ }^{*}$ & KA \\
\hline & Chrysosoma globiferum (Wiedemann, 1830) & Intr & $\sqrt{ }$ & - & - & \\
\hline & Chrysosoma sp. & ? & - & $\sqrt{ }$ & $\sqrt{ }$ & KA \\
\hline & Chrysosoma sp. nr. molestum Parent & ? & - & - & $\sqrt{ }{ }^{*}$ & KA \\
\hline & Chrysotus javanensis de Meijere, 1916 & Nat? & - & $\sqrt{ }$ & - & \\
\hline & Dolichopodidae G. sp. & $?$ & ? & ? & $\sqrt{ }$ & KA \\
\hline \multirow[t]{2}{*}{ Drosophilidae } & Cacoxenus perspicax (Knab, 1914) & Intr & - & - & $\sqrt{ }^{*}$ & KA \\
\hline & Drosophila ananassae Doleschall, 1858 & Intr & - & - & $\sqrt{ }^{*}$ & KK \\
\hline \multirow[t]{6}{*}{ Ephydridae } & Discocerina mera Cresson, 1939 & Intr & - & $\sqrt{ }$ & $\sqrt{ }$ & KA \\
\hline & Hecamede granifera (Thomson, 1869) & Intr & - & $\sqrt{ }$ & - & \\
\hline & Hostis guamensis Cresson, 1945 & Intr & - & $\sqrt{ }$ & - & \\
\hline & Placopsidella marquesana (Malloch, 1933) & Intr & - & $\sqrt{ }$ & - & \\
\hline & Placopsidella sp. & $?$ & - & $?$ & $\sqrt{ }$ & KA \\
\hline & Scatella stagnalis (Fallen, 1813) & Intr & - & - & $\sqrt{ }^{*}$ & KA \\
\hline Hippoboscidae & Olfersia aenescens Thomson, 1869 & Nat? & - & $\sqrt{ }$ & - & \\
\hline \multirow[t]{2}{*}{ Limoniidae } & Limonia sp. nr. perkinsi (Grimshaw) & Intr & - & - & $\sqrt{ }^{*}$ & KA \\
\hline & Styringomyia didyma Grimshaw, 1901 & Nat & - & $\sqrt{ }$ & $\sqrt{ }$ & KA \\
\hline Lonchaeidae & Lamprolonchaea metatarsata (Kertesz, 1901) & Intr & - & $\sqrt{ }$ & $\sqrt{ }$ & KA \\
\hline Milichilidae & Milichiella lacteipennis (Loew, 1865) & Intr & - & - & $\sqrt{ }^{*}$ & KA \\
\hline Muscidae & Atherigona orientalis Schiner, 1868 & Intr & - & $\sqrt{ }$ & $\sqrt{ }$ & KA \\
\hline & Atherigona sp. & $?$ & - & - & $\mathfrak{V}^{*}$ & KA \& NE \\
\hline & Musca domestica Linnaeus, 1758 & Intr & - & $\sqrt{ }$ & - & \\
\hline & Muscidae G. sp. & ? & - & - & $\sqrt{ }^{*}$ & $\mathrm{KA}$ \\
\hline Phoridae & Chonocephalus sp. & ? & - & - & $\sqrt{ }{ }^{*}$ & KA \\
\hline Platystomatidae & Scholastes lonchifera Hendel, 1914 & Intr & - & $\sqrt{ }$ & $\sqrt{ }$ & KA \\
\hline Sarcophagidae & Parasarcophaga misera Walker & Intr & - & - & $\sqrt{ }{ }^{*}$ & KA \\
\hline & Parasarcophaga sp. & $?$ & - & - & $\sqrt{ }{ }^{*}$ & KA \\
\hline & Sarcophaga peregrina (Robineau-Desvoidy, 1830) & Intr & - & $\sqrt{ }$ & - & \\
\hline & Sarcophagidae G. sp. & ? & - & - & $\sqrt{ }^{*}$ & KA \\
\hline Sciaridae & Sciaridae G. sp. & $?$ & - & - & $\sqrt{ }^{*}$ & $\mathrm{KA}$ \\
\hline Stratiomyidae & Cephalochrysa maxima (Bezzi, 1928) & Intr & - & - & $\sqrt{ }^{*}$ & KA \\
\hline Syrphidae & Eristalinus arvorum (Fabricius, 1787) & Intr & - & - & $\sqrt{ }^{*}$ & $\mathrm{WH}$ \\
\hline & Simosyrphus grandicornis (Macquart, 1842) & Intr & - & $\sqrt{ }$ & - & \\
\hline & Syritta sp. & ? & - & - & $\sqrt{ }^{*}$ & KA \\
\hline Tethinidae & Dasyrhicnoessa insularis (Aldrich, 1931) & Nat? & - & $\sqrt{ }$ & - & \\
\hline & Tetbina sp. & $?$ & - & - & $\sqrt{ }^{*}$ & KA \\
\hline Ulididae & Ulididae G. sp. & ? & - & - & $\sqrt{ }^{*}$ & KA \\
\hline
\end{tabular}


Appendix (continued)

\begin{tabular}{|c|c|c|c|c|c|c|}
\hline \multirow[b]{2}{*}{ Family } & \multirow[b]{2}{*}{$\operatorname{Taxa}^{a}$} & \multirow[b]{2}{*}{ Origin $^{b}$} & \multicolumn{3}{|c|}{ Collections $^{c}$} & \multirow[b]{2}{*}{ Determiner $^{d}$} \\
\hline & & & 1913 & 1948 & $\begin{array}{c}2001- \\
2005\end{array}$ & \\
\hline \multicolumn{7}{|c|}{ Order Hemiptera (Heteroptera) } \\
\hline Cynidae & Geotomus pygmaeus (Dallas, 1851) & Intr & - & - & $\sqrt{ }^{*}$ & $\mathrm{WH}$ \\
\hline Gerridae & Halobates micans Eschscholz, 1822 & Nat & $\sqrt{ }$ & - & $\sqrt{ }$ & $\mathrm{DP}$ \\
\hline Lygaeidae & Lygaeidae G. sp. & $?$ & - & - & $\sqrt{ }^{*}$ & \\
\hline Miridae & Trigonotylus brevipes Jakovlev, 1880 & Nat? & - & $\sqrt{ }$ & - & \\
\hline Reduviidae & Reduviidae G. sp. & ? & - & - & $\sqrt{ }^{*}$ & \\
\hline \multicolumn{7}{|c|}{ Order Hemiptera (Sternorrhyncha) } \\
\hline Aleyrodidae & Aleyrodidae G. sp. & Intr & - & - & $\sqrt{ }^{*}$ & \\
\hline Aphididae & Aphididae G. sp. & $?$ & $\sqrt{ }$ & - & $\sqrt{ }$ & \\
\hline Coccidae & Pulvinaria urbicola (Cockerell \& Parrott, 1899) & Intr & - & - & $\sqrt{ }^{*}$ & $\mathrm{BL}$ \\
\hline Margarodidae & Icerya purchasi Maskell, 1879 & Intr & - & $\sqrt{ }$ & $\sqrt{ }$ & WH \\
\hline \multirow[t]{4}{*}{ Pseudococcidae } & Dysmicoccus brevipes (Cockerell, 1893) & Intr & - & $\sqrt{ }$ & - & \\
\hline & Dysmicoccus neobrevipes Beardsley, 1959 & Intr & - & - & $\sqrt{ }^{*}$ & GM \\
\hline & Ferrisia virgata (Cockerell, 1893) & Intr & - & $\sqrt{ }$ & - & \\
\hline & Planococcus citri (Risso, 1813) & Intr & - & $\sqrt{ }$ & - & \\
\hline \multicolumn{7}{|c|}{ Order Hymenoptera } \\
\hline \multirow[t]{2}{*}{ Aphelinidae } & Coccophagus ceroplastae (Howard, 1895) & Intr & - & - & $\sqrt{ }^{*}$ & DG \& MG \\
\hline & Euryischomyia flavithorax Girault \& Dodd, 1915 & Intr & - & - & $\sqrt{ }^{*}$ & DG \\
\hline Cynipidae & Kleidotoma sp. & $?$ & - & $\sqrt{ }$ & - & \\
\hline Diapriidae & Trichopria sp. & ? & - & $\sqrt{ }$ & - & \\
\hline Encyrtidae & Metapbycus flavus (Howard, 1881) & Intr & - & - & $\sqrt{ }^{*}$ & DG \& JN \\
\hline \multirow{2}{*}{ Eulophidae } & Aprostocetus bagenowii (Ratzeburg, 1852) & Intr & - & $\sqrt{ }$ & - & \\
\hline & Hemiptarsenus semialbiclavus (Girault, 1916) & Intr & - & - & $\sqrt{ }^{*}$ & MG \\
\hline Evaniidae & Evania appendigaster (Linnaeus, 1758) & Intr & - & - & $\sqrt{ }^{*}$ & WH \\
\hline \multirow[t]{10}{*}{ Formicidae } & Cardiocondyla emeryi Forel, 1881 & Intr & - & - & $\sqrt{ }^{*}$ & PK \\
\hline & Cardiocondyla minutior Forel, 1899 & Intr & - & - & $\sqrt{ }^{*}$ & PK \\
\hline & Hypoponera punctatissima (Roger), 1859 & Intr & - & - & $\sqrt{ } * f$ & PK \\
\hline & Monomorium floricola (Jerdon, 1851) & Intr & - & - & $\sqrt{ }^{*}$ & DG \\
\hline & Paratrechina bourbonica (Forel, 1886) & Intr & - & - & $\sqrt{ }{ }^{*}$ & NR \\
\hline & Paratrechina longicornis (Latreille, 1802) & Intr & - & - & $\sqrt{ }{ }^{*} g$ & \\
\hline & Paratrechina vaga (Forel, 1901) & Intr & - & - & $\sqrt{ }^{*}$ & NR \\
\hline & Pheidole megacephala (Fabricius, 1793) & Intr & - & $\sqrt{ }$ & $\sqrt{ }$ & NR \\
\hline & Tapinoma melanocephalum (Fabricius, 1793) & Intr & - & - & $\sqrt{ }^{*}$ & WH \\
\hline & Tetramorium bicarinatum (Nylander, 1847) & Intr & $\sqrt{ }$ & - & $\sqrt{ }$ & DG \\
\hline \multirow[t]{2}{*}{ Megachilidae } & Megachile fullawayi Cockerell, 1914 & Intr & - & $\sqrt{ }$ & - & \\
\hline & Megachile sp. & $?$ & - & - & $\sqrt{ }^{*}$ & WH \& TG \\
\hline Scelionidae & Scelionidae G. sp. & ? & - & - & $\sqrt{ }^{*}$ & MG \\
\hline \multirow[t]{2}{*}{ Sphecidae } & Sceliphron caementarium (Drury, 1770) & Intr & - & - & $\sqrt{ }{ }^{*}$ & TG \\
\hline & Sphecidae G. sp. & ? & - & - & $\sqrt{ }^{*}$ & WH \\
\hline \multirow[t]{2}{*}{ Vespidae } & Pachodynerus nasidens (Latreille, 1802) & Intr & - & $\sqrt{ }$ & $\sqrt{ }$ & WH \\
\hline & Polistes aurifer Saussure, 1853 & Intr & - & $\sqrt{ }$ & $\sqrt{ }$ & TG \\
\hline \multicolumn{7}{|l|}{ Order Isopoda } \\
\hline Philosciidae & Australophiloscia societatis (Maccagno, 1932) & Nat & - & - & $\sqrt{ }^{*}$ & DG \\
\hline \multicolumn{7}{|l|}{ Order Lepidoptera } \\
\hline Agonoxenidae & Agonoxena argaula Meyrick, 1921 & Intr & - & $\sqrt{ }$ & - & \\
\hline Cosmopterigidae & Anatrachyntis incertulella (Walker, 1864) & Intr & $\sqrt{ }$ & - & - & \\
\hline Crambidae & Piletocera signiferalis (Wallengren, 1860) & ? & - & $\sqrt{ }$ & $\sqrt{ }$ & WH \\
\hline Gelechiidae & Stoeberbinus testaceus Butler, 1881 & Intr & - & $\sqrt{ }$ & $\sqrt{ }$ & WH \\
\hline Gracillariidae & Gracillariidae G. sp. & $?$ & - & - & $\sqrt{ }^{*}$ & WH \\
\hline Noctuidae & Chrysodeixis eriosoma (Doubleday, 1843) & Intr & - & $\sqrt{ }$ & - & \\
\hline & Spodoptera litura (Fabricius, 1775) & Intr & - & - & $\sqrt{ }^{*}$ & WH \\
\hline Nymphalidae & Hypolimnas bolina Linnaeus, 1758 & Nat? & - & $\sqrt{ }$ & - & \\
\hline Sphingidae & Agrius cingulata (Fabricius, 1775) & Intr & - & - & $\sqrt{ }^{*}$ & WH \\
\hline Tineidae & Erechthias simulans (Butler, 1882) & Intr & - & - & $\sqrt{ }^{*}$ & WH \\
\hline & Opogona sp. & $?$ & - & $\sqrt{ }$ & - & \\
\hline
\end{tabular}


Appendix (continued)

\begin{tabular}{|c|c|c|c|c|c|c|}
\hline \multirow[b]{2}{*}{ Family } & \multirow[b]{2}{*}{$\operatorname{Taxa}^{a}$} & \multirow[b]{2}{*}{ Origin $^{b}$} & \multicolumn{3}{|c|}{ Collections $^{c}$} & \multirow[b]{2}{*}{ Determiner $^{d}$} \\
\hline & & & 1913 & 1948 & $\begin{array}{c}2001- \\
2005\end{array}$ & \\
\hline \multicolumn{7}{|l|}{ Order Odonata } \\
\hline Aeshnidae & Anax junius (Drury, 1770) & Nat & - & - & $\sqrt{ }^{*}$ & DG \\
\hline Coenagrionidae & Ischnura aurora Brauer, 1865 & Nat & - & - & $\sqrt{ }{ }^{*}$ & $\mathrm{RE}$ \\
\hline \multirow[t]{2}{*}{ Libellulidae } & Crocothemis servilia (Drury, 1770) & Intr & - & - & $\sqrt{ }{ }^{*}$ & $\mathrm{RE}$ \\
\hline \multirow{2}{*}{\multicolumn{7}{|c|}{ Order Orthoptera }} \\
\hline & & & & & & \\
\hline Acrididae & Oxya japonica (Thunberg, 1824) & Intr & - & $\sqrt{ }$ & $\sqrt{ }$ & DG \\
\hline \multirow[t]{4}{*}{ Gryllidae } & Cycloptilum sp. & $?$ & - & $\sqrt{ }$ & - & \\
\hline & Ornebius sp. & ? & - & - & $\sqrt{ }^{*}$ & $\mathrm{WH}$ \\
\hline & Speonemobius tigrinus (Saussure) & Nat? & - & $\sqrt{ }$ & - & \\
\hline & Teleogryllus oceanicus (Le Guillou, 1841) & Intr & - & - & $\sqrt{ }^{*}$ & WH \\
\hline Pyrgomorphidae & Atractomorpha sinensis Bolivar, 1905 & Intr & - & $\sqrt{ }$ & $\sqrt{ }$ & WH \\
\hline \multirow[t]{2}{*}{ Tettigoniidae } & Conocephalus saltator (Saussure, 1859) & Intr & - & $\sqrt{ }$ & $\sqrt{ }$ & WH \\
\hline & Phisis boldhausi Karny, 1926 & Nat & $\sqrt{ }$ & $\sqrt{ }$ & $\sqrt{ }$ & WH \\
\hline
\end{tabular}

${ }^{a} \mathrm{G}$. sp. indicates undetermined genus and species.

${ }^{b}$ Refers to biogeographic status on Palmyra (Intr, introduced; Nat, native; ?, cryptogenic).

${ }^{c}$ A check mark $(\sqrt{ })$ indicates that a taxon was collected during a particular time period, as opposed to no collection (-) or an unconfirmed record (?). An asterisk $\left({ }^{*}\right)$ for recent collections indicates a new record for Palmyra Atoll.

${ }^{d}$ Abbreviations refer to: BL, Bertram Lindsey; DG, Daniel Gruner; DP, Dan Polhemus; GAS, G. Allan Samuelson; GM, Gary Miller; JB, Joe Beatty; JN, John Noyes; KA, Keith Arakaki; KK, Ken Kaneshiro; MG, Michael Gates; NR, Neil Reimer; RE, Ron Englund; TG, Tino Gonsalves; WH, William Haines.

${ }^{e}$ Collected July 2002 by C. Depkin.

$f$ Collected November 2003 by P. Krushelnycky and P. Lester.

$g$ Collected November 2003 by M. Richardson. 